Article

\title{
Housing Commons vs. State Spatial Policies of Refugee Camps in Athens and Thessaloniki
}

\author{
Charalampos Tsavdaroglou * and Konstantinos Lalenis \\ Department of Planning and Regional Development, University of Thessaly, 38334 Volos, Greece; \\ E-Mails: tsavdaroglou.charalampos@ac.eap.gr (C.T.), klalenis@uth.gr (K.L.) \\ * Corresponding author
}

Submitted: 15 February 2020 | Accepted: 26 May 2020 | Published: 28 July 2020

\begin{abstract}
Since the European Union's agreement with Turkey on March 18, 2016, more than 70,000 refugees have been trapped in Greece. Most have been settled in state-run camps on the perimeters of Athens and Thessaloniki. However, these state-run camps do not meet international standards and are located at significant distances from urban centres, within industrial zones where residential use is not permitted. At the same time, a number of self-organized and collective refugee housing projects have been created within the urban fabric of Athens and Thessaloniki. In the context of these projects, refugees develop forms of solidarity, mutual help, and direct democracy in decision-making processes. There is a significant volume of bibliography which studies the NGOs' activities and state migration policies. However, little attention has been given to the various ways by which refugees create self-managed and participatory structures to meet their needs. This article aims to fill the gap in the research concerning the production of housing common spaces by the refugees themselves. Based on the current discussions on the Lefebvrian 'right to the city' and the spatialities of 'commons' and 'enclosures,' the article aims to compare and contrast refugee housing commons with state-run refugee camps. Using qualitative methods, including ethnographic analysis and participatory observation, the main findings show that refugees attempt not only to contest state migration policies but also negotiate their multiple identities. Consequently, refugees collectively attempt to reinvent a culture of togetherness, to create housing common spaces, and to claim the right to the city.
\end{abstract}

\section{Keywords}

Athens; Greece; housing policy; mobility; refugees; Thessaloniki

Issue

This article is part of the issue "Urban Arrival Spaces: Social Co-Existence in Times of Changing Mobilities and Local Diversity" edited by Yvonne Franz (University of Vienna, Austria) and Heike Hanhörster (ILS-Research Institute for Regional and Urban Development, Germany).

(C) 2020 by the authors; licensee Cogitatio (Lisbon, Portugal). This article is licensed under a Creative Commons Attribution 4.0 International License (CC BY).

\section{Introduction}

In the aftermath of the European Union and Turkey common statement concerning the refugee crisis on March 18, 2016 (European Council, 2016), and the closure of the borders along the so-called Balkan refugee corridor, more than 70,000 refugees (United Nations High Commissioner for Refugees [UNHCR], 2019) became trapped in Greek territory. The vast majority are now accommodated in 26 state-run refugee camps on the perimeters of Athens and Thessaloniki. However, the state-run camps do not meet international standards for refugees' accommodation (UNHCR, 2007). According to several reports (Greek Council for Refugees, 2019; International Rescue Committee, 2016) and our observations, the camps are overcrowded old factories and abandoned military bases, located at a significant distance from the city centres and in non-residential and hazardous industrial areas. The condition of 'campization' (Kreichauf, 2018) of refugees in these isolated 'spaces of injustice' (Harvey, 1996; Soja, 2010) forces refugees to be invisible and to live in extremely precarious con- 
ditions. Concomitantly, refugee solidarity initiatives occupied abandoned buildings and set up a number of self-managed and collective housing projects in the urban centres of Athens and Thessaloniki. In these selforganized housing projects, refugees develop forms of solidarity, mutual help, and direct democracy in decisionmaking processes and claim their right to the city.

There is a significant volume of important literature which studies the humanitarian NGOs' activities and state migration policies (Afouxenidis, Petrou, Giannaki, Kandylis, \& Tramountanis, 2017; Rozakou, 2012) as well as on the governmentalities, conflicts and policies in refugee camps (Kreichauf, 2018; Pasquetti, 2015; Ramadan, 2013). However, few researchers have looked at how refugees contest state-run camps and create self-managed and participatory housing structures to meet their needs (Della Porta, 2018; Lafazani, 2018; Tsavdaroglou, 2019). This article aims to enrich research concerning the production of housing common spaces by the refugees themselves. Based on current discussions on the spatialities of 'commons' and 'enclosures' (Harvey, 2012; Stavrides, 2019), the article aims to compare and contrast refugee housing commons with staterun refugee camps. In this respect, it follows the call of many works from the 'autonomy of migration' literature (Mezzadra \& Neilson, 2013; Papadopoulos \& Tsianos, 2013) to shift the emphasis from systems and policies of control to the multiple ways that migration reacts to, operates independently from, and in turn shapes those systems and policies.

Moreover, the article takes into account the Lefebvrian (1968/1996) analysis of 'the right to the city,' which concerns urban social movements' struggles for housing, employment, education, culture, and health to include every user and resident of the city. Thus, the article examines how refugees' commoning practices have the ability to contest state migration policies and how refugees can claim visibility, spatial justice, and the right to the city.

The structure of the article is as follows. The following section discusses the theoretical approaches on the right to the city, autonomy of migration and common spaces and their importance in the examination of refugees' right to the city. The next section concerns the methodological approach. The following two sections analyse the spatial policies of the state-run refugee camps and the refugee squats in Athens and Thessaloniki. Finally, the last section concludes with some remarks on refugees' right to the city which we consider important for enriching urban planning.

\section{Theoretical Approach: The Refugees' Right to the City and Mobile Commons}

In order to examine the refugees' right to the city, we must first look at the homonymous work of Henri Lefebvre which claims that the right to the city embodies basic human rights such as "the rights of ages and sexes (the woman, the child and the elderly), the rights of conditions (the proletarian, the peasant), the rights to training and education, to work, to culture, to rest, to health, and to housing" (Lefebvre, 1968/1996, p. 157). However, Lefebvre (1968/1996, pp. 173-174) does not limit his analysis to the legal or juridical form of human rights but instead clearly emphasizes that the right to the city "manifests itself as a superior form of rights: the right to freedom, to individualization in socialization, to habitat, and to inhabit. The right to the oeuvre, to participation and appropriation...are implied in the right to the city." Thus, Lefebvre conceptualizes the right to the city as a social relation that collectively claims participation in the urban society, in such a way that it produces the city as a place of freedom, co-habitation, and togetherness. As he stresses, "the right to the city is like a cry and a demand...a transformed and renewed right to urban life" (Lefebvre, 1968/1996, p. 158). Consequently, the Lefebvrian right to the city is not simply a right to the physical space of the city, but a claim to urban social life. It is the right of every user and resident of the city. Finally, as Lefebvre notes that the right to the city concerns also "the right to the use of the centre, a privileged place, instead of being dispersed and stuck in ghettos (for workers, immigrants, the 'marginal')" (Lefebvre, $1996 / 1968$, p. 34). This is particularly important in examining the refugees' right to the city, in terms of planning policies which emphasize their ability to exercise their right to the city centre, and everyday social relations.

Recently, several scholars (Harvey, 2012; Tsavdaroglou, 2018) have tried to enrich the Lefebvrian analysis on the right to the city with a discussion on commons and enclosures. 'Commons' usually refers to the territories that are "governed by a group of people, the commoners, and a social relationship that underpins that governance" (Chatterton, 2010a, p. 901). Commons stand against enclosures, the processes of privatization and the prohibition of access to common-pool resources. Over time and across space, there have been a plethora of struggles and conflicts around the dialectic of common spaces versus privatized spaces. In light of this, as Chatterton (2010b, p. 626) pointed out, "the common is full of productive moments of resistance that create new vocabularies, solidarities, social and spatial practices, and relations and repertoires of resistance." The most crucial notion of these new vocabularies is perhaps the so-called 'commoning,' which concerns the social relations that produce and reproduce the common. The term is introduced by Linebaugh, and as he explains, "I use the word because I want a verb for the commons...I want to portray it as an activity, not just an idea or material resource" (as cited in Ristau, 2011). This conceptual shift from 'commons as resources' to 'commons as relational social frameworks' (Bollier \& Helfrich, 2015) opens up fruitful new theoretical avenues on "the continuous making and remaking-the (re)production of the commons through shared practices" (Ruivenkamp \& Hilton, 2017, p. 1). In addition, as De Angelis (2010, 
p. 955) has argued, "there are no commons without incessant activities of commoning, of (re)producing in common," which is important for communities in order to "decide for themselves the norms, values, and measures of things" (De Angelis, 2010, p. 955). Closing this brief review on commons, it should be noted that several thinkers (Caffentzis, 2010; Hardt \& Negri, 2009) have highlighted the lack of state or private control, regulation, and management as being a key feature of the commons.

Subsequently, under the prism of the commons, the right to the city could be seen as urban commoning relations that collectively appropriate, produce, and protect common spaces for every user-commoner, and especially for marginalized residents such as the newcomer refugees. As Stavrides (An Architektur, 2010, p. 17) states, the right to the city "can be produced through encounters that make room for new meanings, new values, new dreams, new collective experiences. And this is indeed a way to transcend pure utility, a way to see commons beyond the utilitarian horizon." Consequently, the question of refugees' right to the city should concern not only the urban physical space but also the social spaces of encounters, dreams, values, and solidarities.

In this respect, the recent strand of thought on the 'autonomy of migration' offers the lenses to conceptualize the so-called 'mobile commons' of moving populations. Several scholars (Bakewell, 2010; Faist, 2000; Massey et al., 1993) have examined the complex question of agency and structure in relation to migration processes. Focusing on the agency and self-activity of moving populations, scholars of the autonomy of migration (Mezzadra \& Neilson, 2013; Papadopoulos, Stephenson, \& Tsianos, 2008) criticize and attempt to "dethrone" (Olmos, 2019, p. 7) the structural approaches that regard refugees as mere passive recipients of state policies or humanitarian NGOs' activities. In contrast to the victimization and the paternalistic approach of institutional policies, proponents of the autonomy of migration (Mezzadra \& Neilson, 2013; Trimikliniotis, Parsanoglou, \& Tsianos, 2015) highlight refugees' subjectivities and their creative capacity to contest physical and social border policies and form mobile commons that are based on "shared knowledge, affective cooperation, mutual support and care between migrants" (Papadopoulos \& Tsianos, 2013, p. 179).

Overall, taking into account the aforementioned approaches, we aim to show how state-run camps constitute physical and social borders which prevent the refugees' from claiming their right to the city. We also demonstrate how self-organized housing projects within the city centre could be considered as common spaces offering refugees the potential to claim and invent spatial justice and the right to the city.

\section{Methodology}

Athens and Thessaloniki were selected as case studies for two reasons. First, they are the most populated ur- ban areas in Greece, hosting almost half of its total population, with the highest number of state-run refugee camps. Second, they are the only cities with refugee squats in mainland Greece. Athens is the capital of the country and its' port Piraeus is the point of entry for refugees moving from the islands to the mainland. Thessaloniki is the biggest city in northern Greece and the site where refugees were relocated from the informal settlement of Idomeni, on the border with North Macedonia, in the summer of 2016 . Each city hosts about 15,000 refugees in 13 state-run camps (Coordination Centre for the Management of Refugee Crisis in Greece, 2016), and more than 3,000 refugees in self-organized occupied buildings. In the rest of the mainland, 10,000 other refugees are living in state-run camps while around 30,000 live in state-run camps on islands. Thus, $75 \%$ of the refugees in mainland Greece currently live within the two examined cities. The vast majority of refugees are from Syria, Afghanistan, Iraq, and Pakistan (Asylum Information Database, 2018).

The Athens conurbation, with approximately 3.8 million residents, is about four times larger than Thessaloniki, however, both cities have a similar urban structure, characterized by their dense urban structure and mixed land use. The commercial, touristic, and administrative functions are based in the centre, high economic strata are mainly in the eastern areas of each city, while the low-income areas and industrial zones are located on the west sides of both cities. Most of the staterun refugee camps are located within or around the industrial zones (see Figures 1 and 2).

The research was based on qualitative methods, direct observation, spatial and ethnographic analysis. Fieldwork was conducted in the 26 state-run refugee camps and 15 squats in both cities from autumn 2017 until summer 2019. We carried out 60 semi-structured interviews, 30 per city because the two cities have approximately the same number of refugees (see Table 1), and several informal conversations with refugees living in both state-run camps and self-organized refugee squats in the two cities. While 30 interviews concern the staterun camps and 30 the self-organized squats, most of the squats' residents had experienced living in state-run camps which brought the total number of interviews about the state-run camps to 52 . We aimed to have 2 interviewees, usually one male and female from each structure, state-run camps or squats, thus there were 60 interviews in total. The participants in the research were from Syria, Iraq, Iran, Afghanistan, Pakistan, Algeria, and Morocco, the main countries of origin for refugees (Asylum Information Database, 2018); all were adults, 28 males and 28 females and 4 who self-identified as transgender and queer.

The research interviews and conversations with refugees were conducted in either Greek or English with the help of interpreters when translation from Arabic, Urdu, and Farsi was needed. The biggest difficulty that we faced was that the majority of the interpreters were 


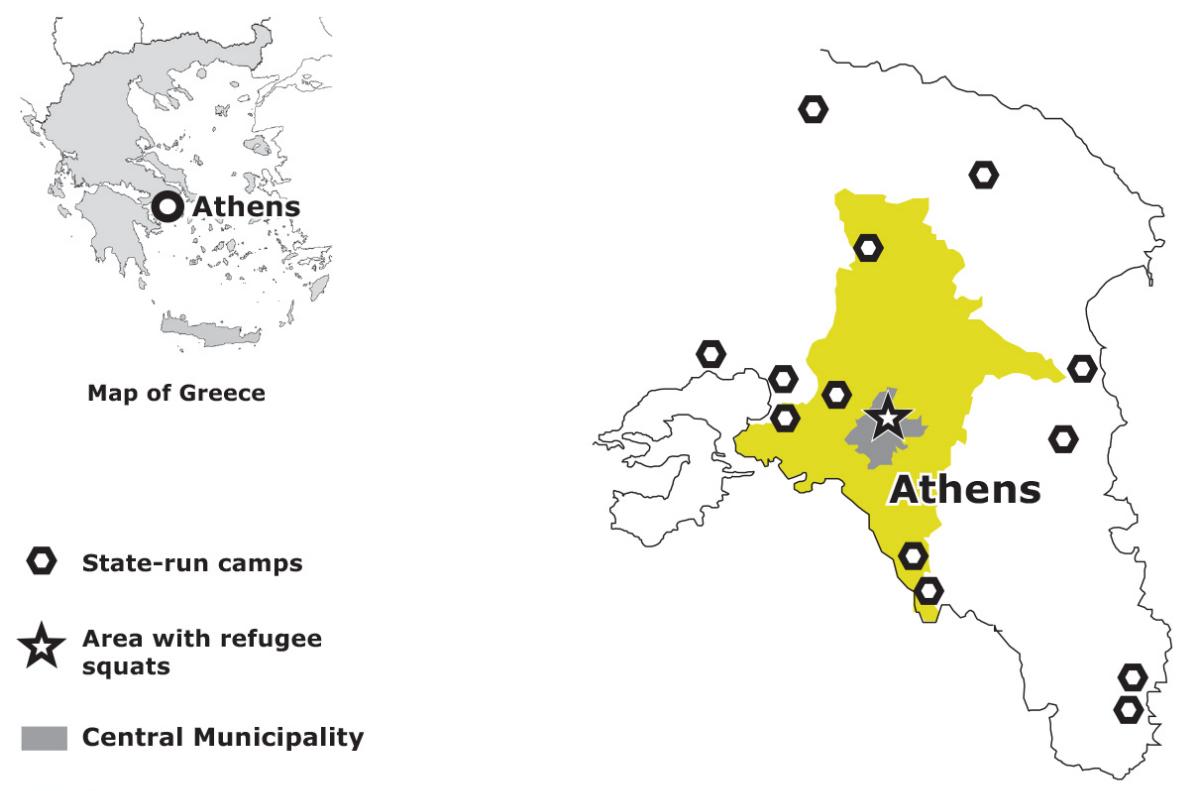

Urban area

Urban area population: 3,8 million residents

Urban area size : $412,000 \mathrm{~km}^{2}$

Figure 1. Locations of state-run refugee camps and refugee squats in Athens. Source: Authors, based on the land use map of Regulatory Urban Plan of Athens and Thessaloniki Metropolitan Areas (2014).

male and in cases where the interviewee was female, we had to find a female interpreter to secure their trust and avoid discomfort. The interviews and conversations were organized according to the requirements of the participants, in familiar and easily accessible locations, such as coffee shops, public squares, and the self-organized squats so as to minimize any inconvenience.

Also, our positionality as Greek and European citizens involved complexities which had to be taken into consideration in the research analysis. For example,

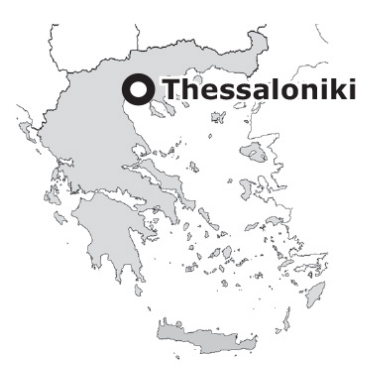

Map of Greece

- State-run camps

t Area with refugee

squats

Central Municipality

Urban area o

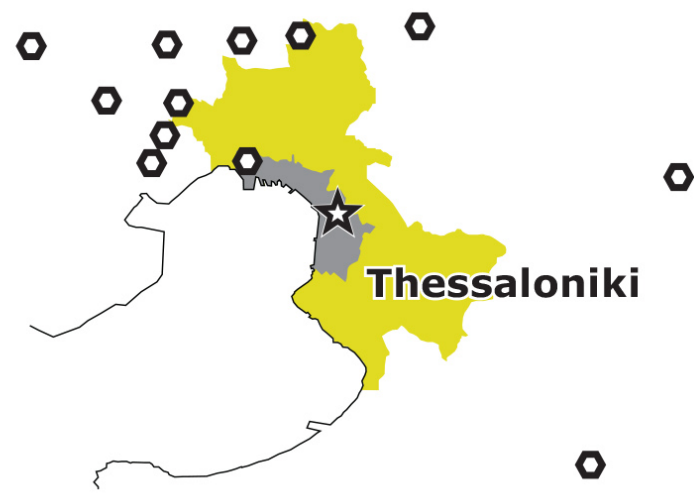

Urban area population: 1,1 million residents

Urban area size : 112,000 km²

$0 \mathrm{~km} 2,5 \mathrm{~km} 5 \mathrm{~km}$

Figure 2. Locations of state-run refugee camps and refugee squats in Thessaloniki. Source: Authors, based on the land use map of Regulatory Urban Plan of Athens and Thessaloniki Metropolitan Areas (2014). 
Table 1. Interviews sample.

\begin{tabular}{lrr}
\hline & Athens & Thessaloniki \\
\hline Number of refugees & 15,684 & 15,395 \\
Number of interviews & 30 & 30 \\
Number of interviews concerning only state-run camps & 15 & 15 \\
Number of interviews concerning only squats & 6 & 6 \\
Number of interviews concerning both squats and state-run camps & 9 & 9 \\
Number of male interviewers & 14 & 14 \\
Number of female interviewers & 2 & 2 \\
Number of transgender and queer interviewers & 23 & 24 \\
Number of interviews in English & 7 & 6 \\
Number of interviews in Greek & 74 \\
\hline
\end{tabular}

'empty promises' should not be made to the refugee participants regarding their future legal status, and refugee-participants' activities should not be exoticized or fetishized.

Finally, we should point out that we have replaced participants' real names with culturally appropriate pseudonyms in order to protect their identities. The anonymisation guarantees that no harmful social consequences affect the refugee participants as a result of taking part in the research.

\section{Spatial Policies of Campization: State-Run Refugee Accommodation Centres}

The refugees' right to affordable housing and public services is recognized by several international, European, and national statements, agreements, and laws (European Council on Refugees and Exiles, 2007; Greek Government, 2018; United Nations Committee on Economic, Social and Cultural Rights, 1991). However, numerous NGOs (Greek Council for Refugees, 2019; International Rescue Committee, 2016) have severely criticized the living conditions of the state-run camps in Athens and Thessaloniki and emphasized that they do not meet the international standards for "security of tenure, availability of services, affordability, habitability, accessibility and cultural adequacy" (UNHCR, 2014, p. 4).

According to Mahmoud, a Moroccan male refugee who stayed in a camp on the outskirts of Thessaloniki for one year:

The living condition in the camp is absolutely unacceptable. Very dirty, disgusting places, they do not offer anything to refugees, even the water is unsuitable for drinking or showering. Very few toilets, always dirty and never hot water. The government just threw the refugees into the tents, the phrase that is prevalent in the mouths of all the refugees is that "the camps are a slow death. (Personal interview, April 10, 2019)

Also, noteworthy are the words of Karima, a refugee woman from Syrian, who lived in a camp outside of Athens:
I have nothing to do at the camp, only to talk to other refugees about the bad things going on inside the camp. The camp is like a strange prison, cut off from the outside world, living in a parallel ghetto-like reality. You talk about ugliness, you get upset, you play with your mobile phone in your container and then you sleep, this is the life in the camp. (Personal interview, June 22, 2019)

According to our research, the 13 state-run refugee camps in Athens and the 13 camps in Thessaloniki used to be military bases and abandoned factories or warehouses at a considerable distance from the city centres; this varied, from $15 \mathrm{~km}$ to $70 \mathrm{~km}$ (see Figures 3 and 4). These places are the ruins (Ziindrilis \& Dalakoglou, 2019) of the postwar industrialization and militarization of the country. They are the expression of the massive postwar industrial development of Athens and Thessaloniki, and the Cold War policies of militarization, as the country is located on NATO's South Eastern edge next to the Eastern ex-Communist bloc. However, after the fall of the Berlin Wall, the emergence of post-Fordism and the de-industrialization of the country left vast areas of factories and military bases on the perimeter of Athens and Thessaloniki abandoned. These are the sites of the refugee camps.

Consequently, all of the refugee camps are far from hospitals, schools, playgrounds, green spaces and parks, as well as public services, local markets, churches, cafes, restaurants, and sports and leisure services. In fact, the majority of the camps are located in the most degraded and environmentally polluted areas of the Thessaloniki and Athens metropolitan complexes, far from the city centres and the middle or upper-class neighbourhoods and suburbs. The areas in which the camps are located are covered with abandoned factories and warehouses as well as other forms of land use such as prisons, oil refineries, and shipyards.

The Ministry of Migration and Asylum decided on the locations of the state-run camps in a haste, as the borders in the Balkan corridor closed in March 2016 and some thousands of refugees were trapped inside the Greek territory. Until then, Greece did not have 


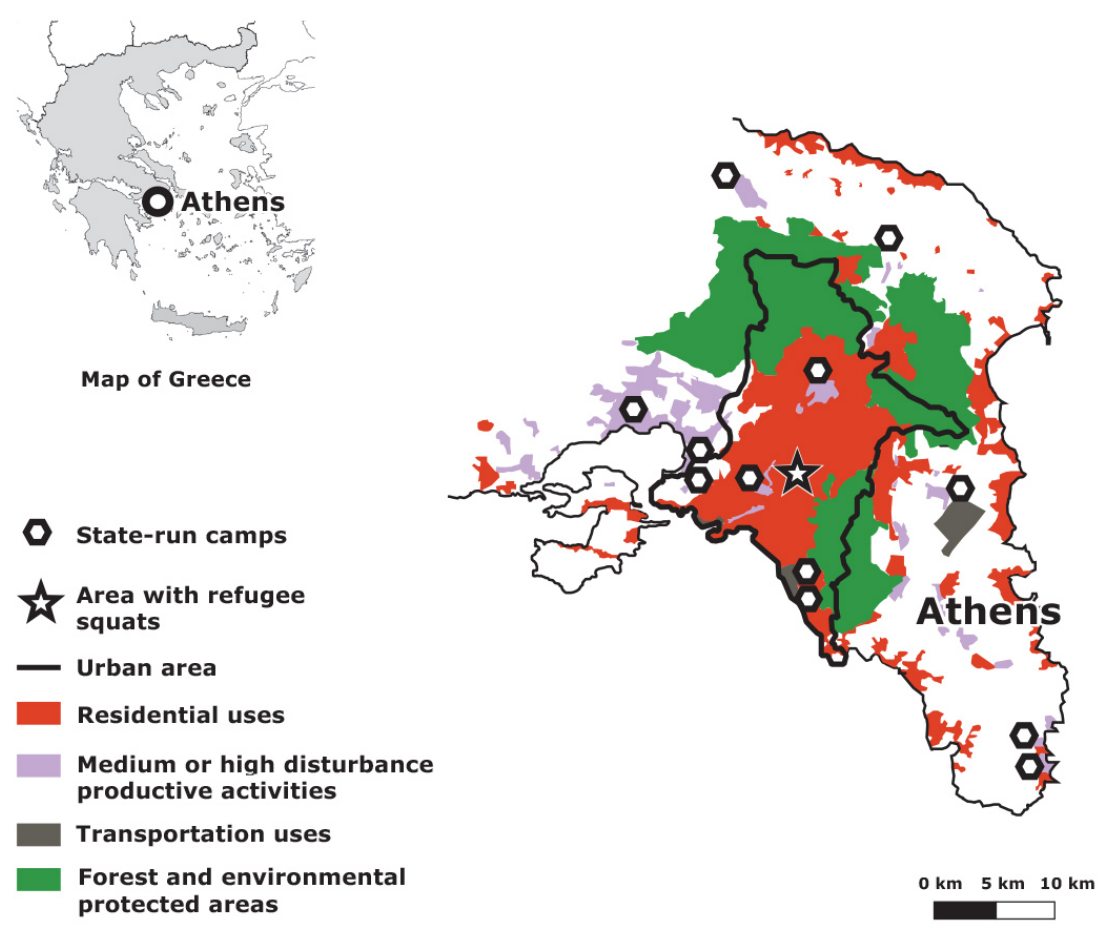

Figure 3. Land use and locations of state-run camps and refugee squats in Athens. Source: Authors, based on the land uses map of Regulatory Urban Plan of Athens and Thessaloniki Metropolitan Areas (2014).

organized accommodation centres for refugees. Thus, the state "urgently and under pressure" (Pechlidou, Frangopoulos, \& Hatziprokopiou, 2020, p. 168) followed a 'fast track' process, limiting consultation with local authorities to one invitation to propose possible loca- tions for camps. According to the Ministry coordinators and media press release (Ministry of Interior, 2015), most of the mayors in the conurbations of Thessaloniki and Athens refused to propose locations, following a "not in my back yard" attitude (Pechlidou et al., 2020).

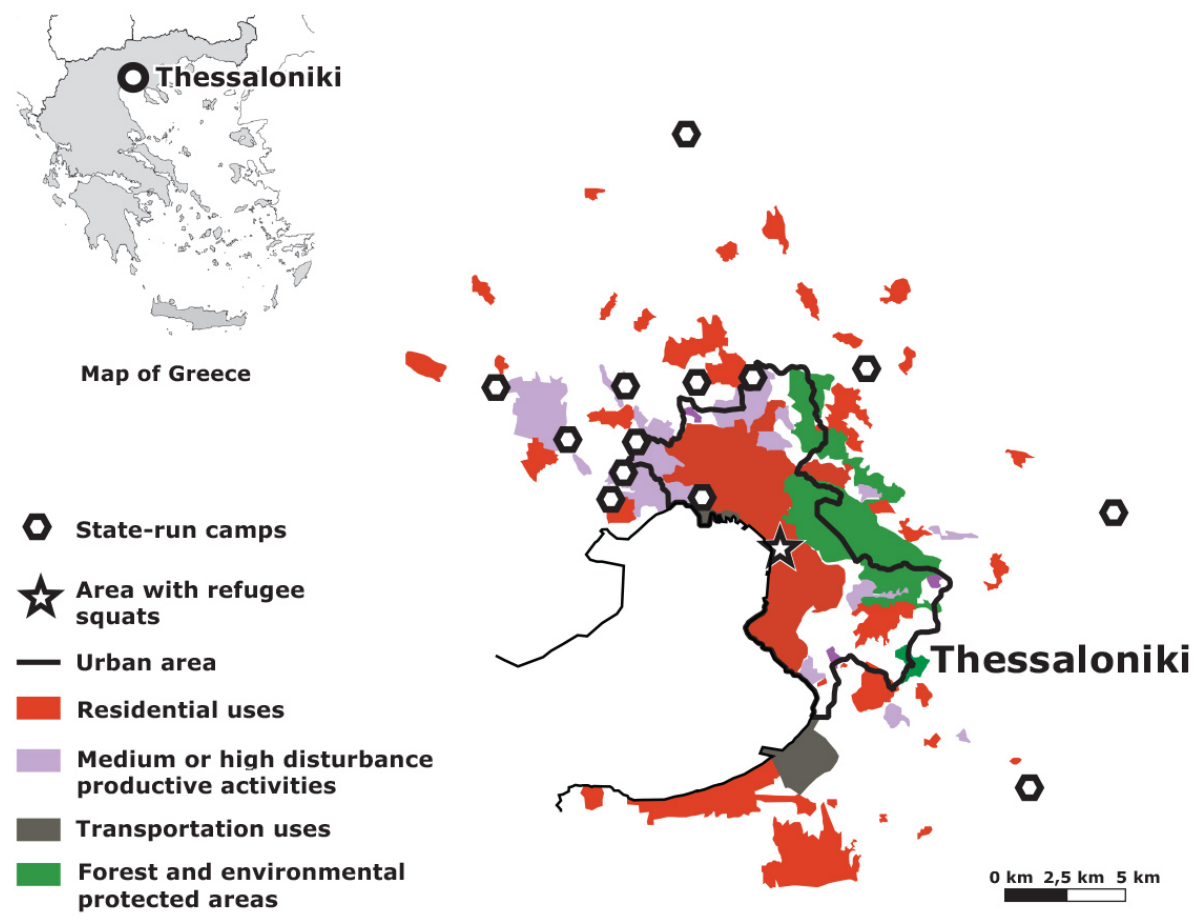

Figure 4. Land use and locations of state-run camps and refugee squats in Thessaloniki. Source: Authors, based on the land uses map of Regulatory Urban Plan of Athens and Thessaloniki Metropolitan Areas (2014). 
According to Gemenetzi and Papageorgiou (2017, p. 67), the state's "housing choices [were made] without clear and transparent spatial criteria in the context of a comprehensive housing policy." Consequently, refugee camps were located in the most degraded, low-income areas of Athens and Thessaloniki. Their establishment triggered xenophobic reactions by neighbouring residents, frequently supported by several local mayors, who signed petitions against camp locations with the pretext of there being a lack of information and consultation (Pechlidou et al., 2020).

Although similar procedures were followed when deciding the location of the camps in both cities, there were two differences worth noting. In the case of Thessaloniki, the vast majority of the camps were located in the west part of the city with only one camp being located on the east side (see Figure 4), while in Athens it seems that they were more equally allocated around the urban area (see Figure 3). Moreover, as mentioned above, the number of refugees in the two cities is almost the same, and since Athens is four times larger than Thessaloniki in terms of population and urban area (see Table 1), the percentage of refugees per local population is much higher in Thessaloniki (around 14 refugees/1,000 residents) than in Athens (approximately 4 refugees/1,000 residents).

Furthermore, according to the Regulatory Urban Plan of Athens and Thessaloniki Metropolitan Areas (2014), in the areas of the refugee camps, residential uses are prohibited and only 'medium or high disturbance productive activities' are permitted (see Figure 5). Also, accord- ing to European Union's Seveso Directive: Technological Disaster Risk Reduction (EUR-Lex, 1997) and on the basis of the national Large-Scale Technology Accident Response Plan (Ministry of Interior, General Secretariat for Civil Protection, \& Department of Emergency Planning and Response, 2009), several state-run camps are located within industrial accident hazard zones as they are adjacent to oil refineries, petroleum product processing plants, as well as liquid and gas fuels depots (see Figure 5).

In addition, it is remarkable that according to UNHCR's (2007, p. 210) design standards of refugee accommodation centres, at least 30 square meters should be provided for each resident as the minimum acceptable level for decent living conditions, and 45 square meters including open spaces, roads, footpaths, administration, and all shared uses in the camp. However, in most of the state-run refugee camps in Athens and Thessaloniki, the size of the camp area is significantly smaller, measuring 25 square meters per resident in Skaramagas camp in Athens including open areas and only 15 square meters per resident in Softex camp in Thessaloniki. Also, it is worth noting that the above sizes are considerably lower than the Greek national urban planning standards (Greek Government, 2004) which is set at 45 square meters per resident for affordable housing, increasing to more than 100 square meters when including roads, green areas, and open public spaces.

Thus, we argue that the accommodation of refugees in isolated and inappropriate state-run camps is close to

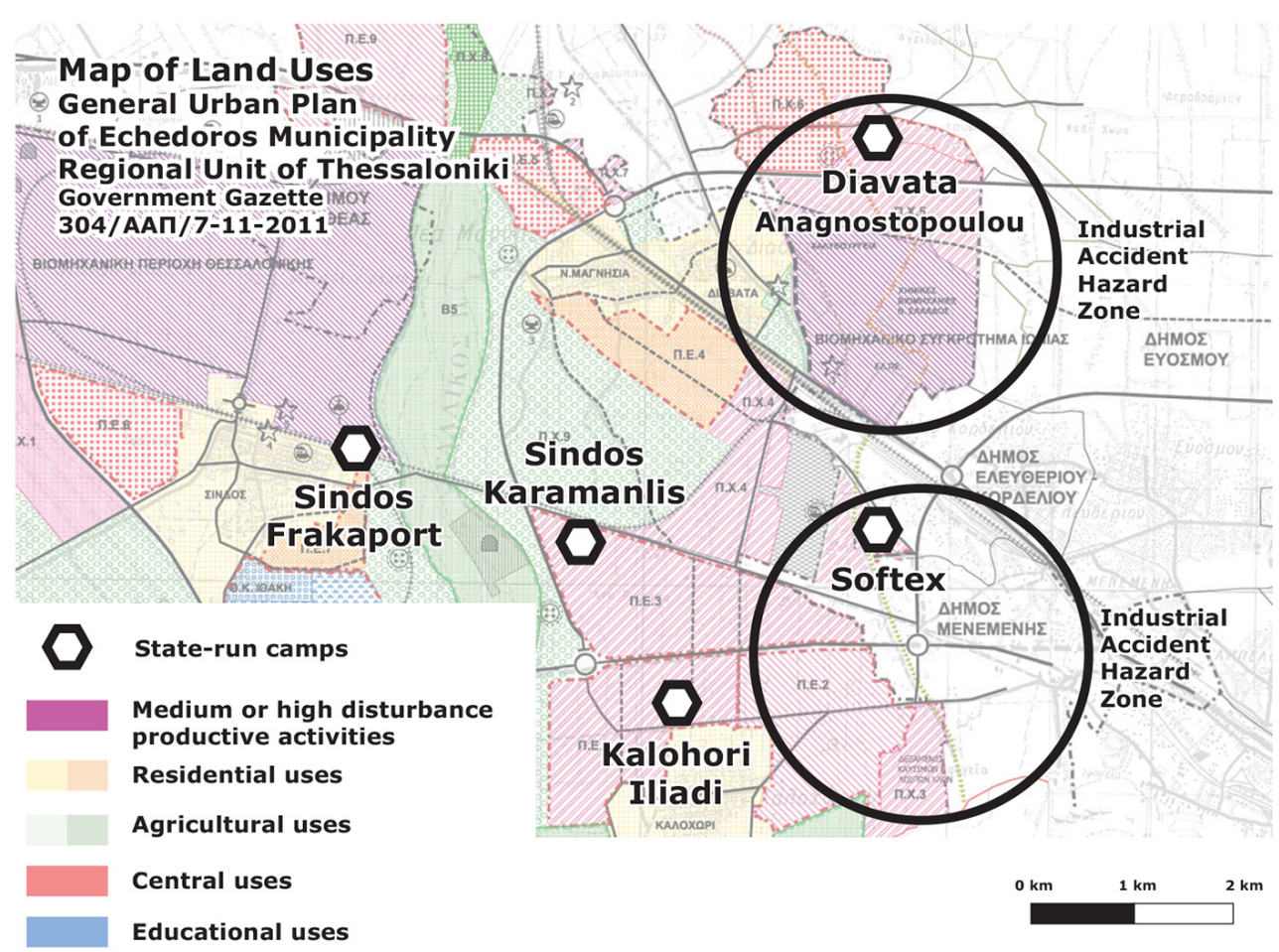

Figure 5. Map of land use in the municipality of Echedoros in the regional unit of Thessaloniki and positions of state-run refugee camps. Source: Authors, based on the land uses map of the General Urban Plan of Echedoros Municipality (Greek Government, 2011). 
the notion of 'spatial injustice' (Harvey, 1996; Soja, 2010) as the spatial separation and discrimination between the city residents and the containment of refugees in camps produces a "regime of marginality" (Wacquant, 2007, p. 67) and a "territorial stigmatization" (p. 68). Therefore, we argue that the aforementioned features, conditions, and positions of the state-run refugee camps constitute an exceptional spatial legal status, and as Turner (2016, p. 141) has aptly pointed out, "they are legally under the jurisdiction of the host society but also exempted from it." This exceptional spatiality is adjacent to the notion of 'campization' of refugees which according to Kreichauf (2018, p. 14) is the production of a space that is "developed to separate the 'own' and the '(ethnic) stranger'; citizens and non-citizens" it is an "exceptional place, which has been developed to house this particular group and not citizens." In the cases of Athens and Thessaloniki, this campization is expressed in socio-spatial isolation, restrictive and exceptional spatial policies, and low standards of living, with the inevitable consequence that most of the refugees suffer from psychosocial and mental health problems and post-traumatic stress disorder. In the words of Sara, an Iraqi female refugee who lived within camps in Athens for two years:

All refugees when leaving the camps have psychological problems and trauma, because they spent most of the time inside the tents or the containers looking out of the window, as if they are imprisoned, desperate, frustrated, doing nothing. I really cannot understand the logic of keeping refugees out of the city and treating in this inhuman way. (Personal interview, April 28, 2019)

According to several reports and our observations, women and LGBTQ (lesbian, gay, bisexual, transgender and queer) persons face a high risk of gendered, homophobic, and transphobic based violence, sexual abuse and harassment in the state-run camps. As Liapi, Charidou, and Tyrovolas (2016, p. 41) argue, "limited attention is paid to the prevention of gender-based violence through the implementation of actions to empower women themselves" while as they stress (Liapi, Giannopoulou, Tyrovolas, Kountouri-Tsiami, \& Saratsi, 2019, p. 57) "inadequate and inefficiently trained personnel, whose capability of recognizing the signs of gender-based violence is not guaranteed, limits, even more, the effective identification of gendered based violence survivors."

The harsh conditions in the state-run camps have inspired refugees' self-organized protests, such as hunger strikes demanding better quality food, hygiene, and living conditions (Tsavdaroglou, 2019). However, such expressions of resistance and agency were typically met with violent repression by the police.

Given the above conditions, it is not surprising that refugees look for alternative forms of housing and to gain access to the city and its urban social life.

\section{Inventing Spatial Togetherness: Refugees' Housing Commoning Practices}

In contrast to the conditions in the abovementioned state-run camps, numerous refugee housing squats emerged in the city centres of Athens and Thessaloniki from 2015 to 2019 (see Figures 6 and 7). Most of the squats were abandoned public or private buildings, which were occupied by refugees and solidarity leftist and anarchist solidarity groups. In these spaces, locals, international volunteers, and refugees try to establish an everydayness of taking decisions together, learning from each other and challenging national, political, religious or other identities. According to several scholars (Agustín \& Jørgensen, 2019; Lafazani, 2018; Tsavdaroglou, 2018), as well as findings from our own research, these housing projects are managed as common spaces as they are based on the values and principles of commoning, non-hierarchical participation, mutual caring, and direct democratic processes. Moreover, these occupied buildings can be considered as commons as they constitute a physical common resource and social commoning process for newcomers who are exercising togetherness and sharing inhabitance, intercultural interactions, and caring personal relationships. Accordingly, the refugee squats seem to follow the principles of mobile commons as outlined by Papadopoulos and Tsianos (2013), that is sharing of knowledge, infrastructures of connectivity, informal economies, transnational communities of justice, and politics of care. These features transform the occupied buildings from empty spaces into open spaces for newcomers beyond the camps' physical and social borders and the NGOs' or state's immigration management.

When we asked Babak, an Iranian male refugee who had lived for one year in camps in the perimeter of Athens before becoming a resident of the Themistokleous 58 squat in the centre of Athens, to describe the main differences between life in a state-run camp and life in a refugee squat he said that:

In contrast to the camps, the squats are in the centre of the city, they are proper buildings in which we are protected from the weather conditions, while in the containers and tents in the camps refugees are vulnerable to wind and rain as well as to winter cold and summer heat. However, the most important difference is that in the squat we feel like we are part of it, we can shape it, we can participate in activities, while in the camp it is like you are in a peculiar cage, there are surveillance mechanisms everywhere, there are cameras and police control the refugees every day. (Personal interview, April 10, 2019)

Mehdi, an Afghan male refugee who has lived for six months in a camp outside of Athens and for one year in the Refugee Accommodation and Solidarity Space City Plaza squat in Athens said: 


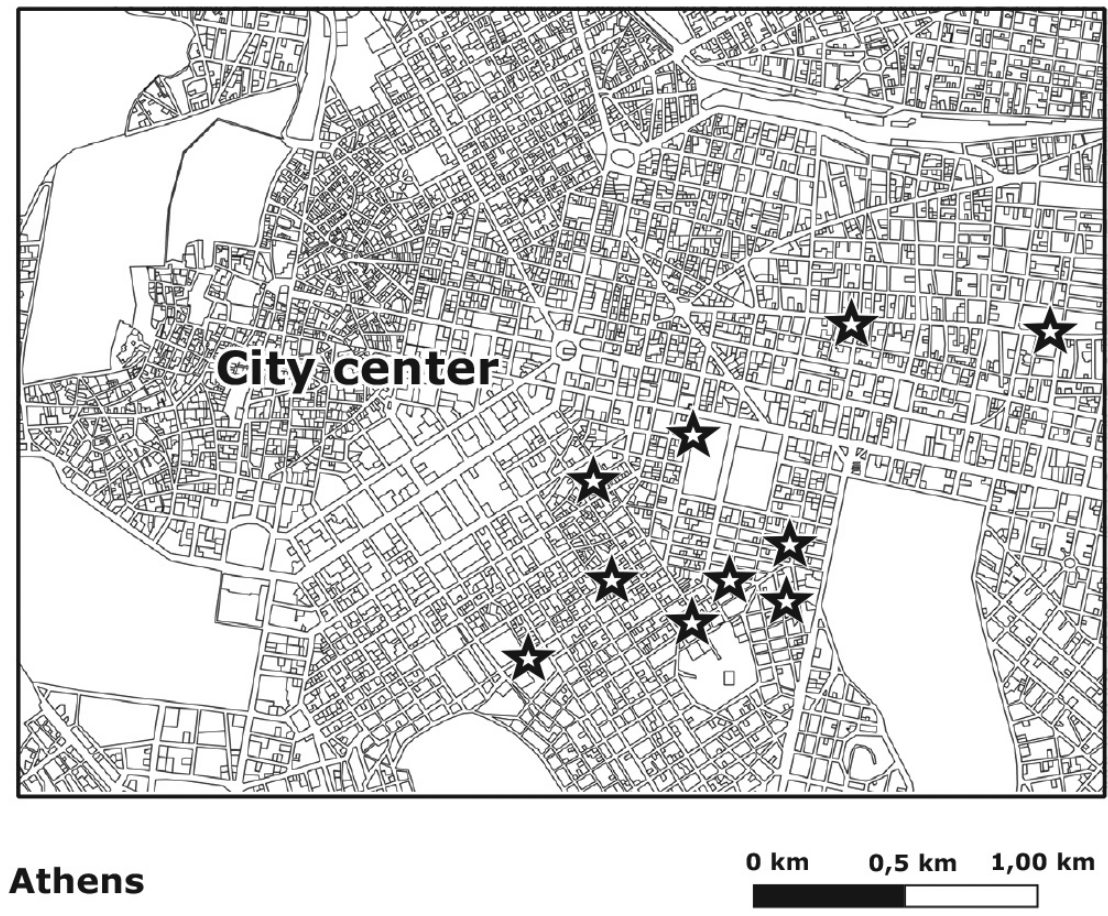

A Refugee housing squats and common spaces

Figure 6. Refugee housing squats and common spaces in Athens. Source: Authors, map based on the land uses map of Regulatory Urban Plan of Athens and Thessaloniki Metropolitan Areas (2014).

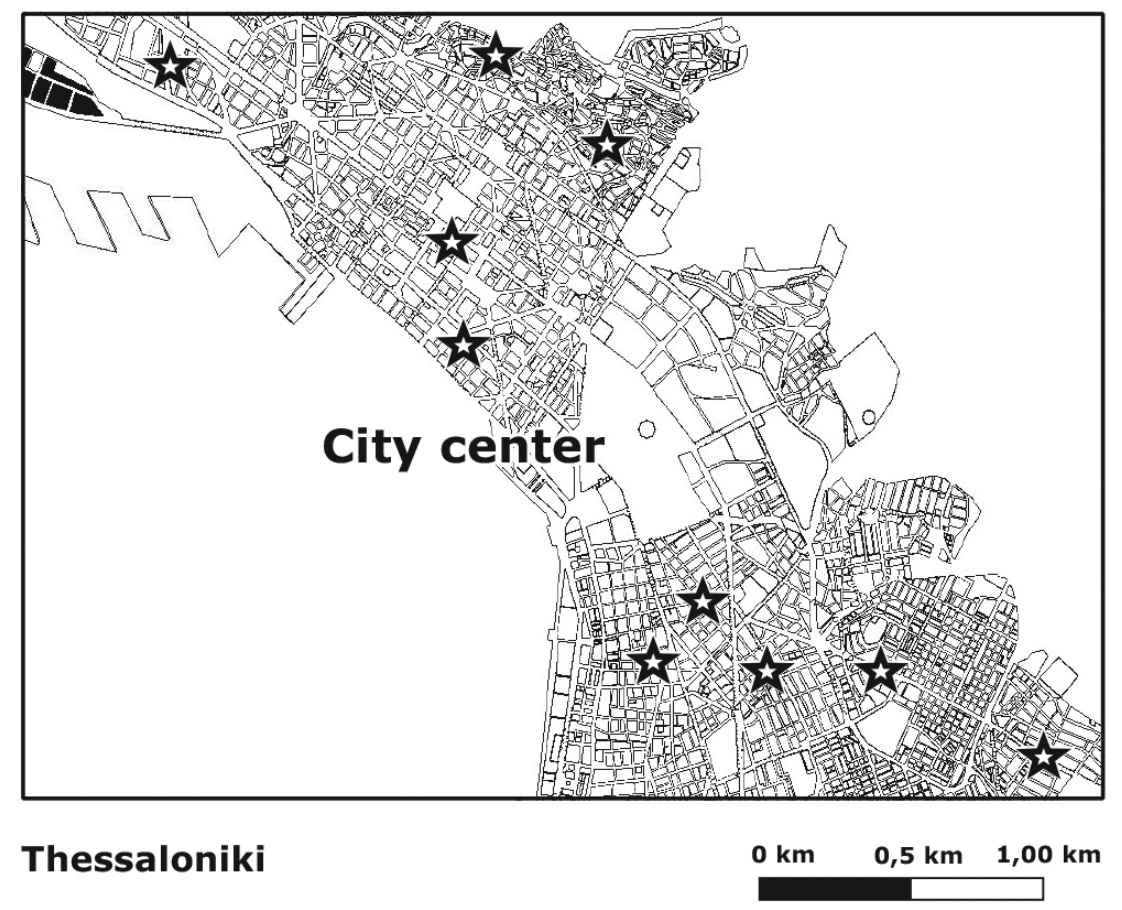

太 Refugee housing squats and common spaces

Figure 7. Refugee housing squats and common spaces in Thessaloniki. Source: Authors, map based on the land uses map of Regulatory Urban Plan of Athens and Thessaloniki Metropolitan Areas (2014). 
In the squat there are no NGOs or state interventions, here we live together and we do all the tasks together. There are no walls between refugees and solidarity people, or between different nationalities. Here we are all equal and there is respect and absolute freedom of expression and speech. Nobody imposes on the other what they should and should not do. We rely on free consciousness and we support each other. (Personal interview, April 10, 2019)

Communicating and analysing the significance of the mutual support practices, self-organization, and direct democracy in transforming the abandoned buildings into housing commons, does not however imply that there were not challenges involved and a struggle to overcome them. According to both our research and analysis provided in relevant works (Agustín \& Jørgensen, 2019; Lafazani, 2018), most of the newcomers are not familiar with processes of direct democracy and non-hierarchical participation. As Lafazani (2018, p. 902) emphasizes:

Many, perhaps due to the sociopolitical structure of their countries of origin and through the process of crossing the European borders, carry a sense of subalternity when face-to-face with European solidarity activists. They do not perceive themselves as equal interlocutors who can be involved in decision-making processes.

Hence, efforts for equal participation across lines of nationality, religion, and gender, as well as negotiations of the multiple emergent power relations, although key aspects in these projects, were often hard to achieve. Moreover, due to intense pressure to accommodate large numbers of newcomers, sometimes refugee squats turn into overcrowded spaces that do not meet the official national or international design standards of refugee accommodation centres. However, the commitment to a sense of collective community and to accepted inviolable standards, leads the occupants to try to organize the buildings according to the needs of their residents; wherein each family usually lives in a separate room, single women have distinct safe places, and alcohol, drugs, and any form of physical violence are strictly prohibited.

One of the most important features of the squatted buildings is that they are located within a short walking distance of schools, hospitals, employment opportunities, and public services. Thus, the refugees are able to cultivate a feeling of sociability, familiarity, and intimacy with the city and its urban social life. In the case of Athens, as Agustín and Jørgensen, (2019, p. 59) describe, the squatted buildings "are often located close to anarchist squats and social centres that also protect the refugee squats against fascist and right-wing militant mobilizations." Indeed, most of the refugee squats in Athens are located in, or near the perimeter of the Exarcheia neighbourhood, an area in the city centre where a counter-culture has historically been developed and where anarchist and left-wing political communities reside. In the case of Thessaloniki, the squatted buildings are scattered throughout the city's central neighbourhoods, which means that refugees interact with a wide and varied range of people from the local communities. In the words of Rima, a female refugee from Syria, who lived for six months in state-run camps and then for eight months in the Orfanotrofio Housing Squat for Immigrants in the centre of Thessaloniki:

I believe that if the refugees get involved with the local population this will be useful to both the refugees and the local community. This will break stereotypes on both sides, and at the same time, this will make refugees to feel better and to be useful to this place. It is very important to have inside the city meeting places for locals and newcomers, like the squat of Orfanotrofio, in order people to have a living experience and knowledge of the other that is not mediated by dominant images produced by the mainstream media. (Personal interview, December 21, 2018)

Furthermore, as a statement by the Refugee Accommodation and Solidarity Space City Plaza (2019) in Athens declares, the two main goals of the squat are "to create a space for safe and dignified housing for migrants in the centre of the city, a space of solidarity and cooperation between locals and migrants" and "to function as a centre of struggle in which political and social demands by migrants and locals will interweave and complement each other." Also, in the words of Amira, a Pakistani female refugee who lived for five months in state-run camps and then moved to the self-organized Housing Squat for Immigrants Orfanotrofio in Thessaloniki:

At the squat, I first saw people who cared about me, who helped me with the asylum procedures, who helped me when I needed to go to the hospital, and of course, I found a safe house. Most importantly, I participate in the political assembly and I have an active role in organizing demonstrations and protests for the freedom of movement of refugees and against detention centres. (Personal interview, November 21, 2018)

Finally, many of the self-organized structures provide safe spaces for LGBTQ refugees. Indicative are the words of Jasmine, a transgender woman refugee from Iran who lived for eight months in state-run camps outside Thessaloniki and later joined the refugee LGBTQ group Eclipse in the centre of Thessaloniki:

I live in an occupied house in the centre of the city with people from the queer group Eclipse. In contrast to the experiences I had in the camps where I was afraid to walk around and I was constantly hiding because everyone was looked at me really weird, now, I feel safe and I participate in the activities of Eclipse 
refugees LGBTQ group. I am very impressed by the self-organized approach on gender issues and I am happy to meet other transgender refugees from many other countries. All the people in the team have made me feel strong and proud of who I am, and I wish to transfer this feeling to other people who suffer and face the difficulties that I faced. And I want to emphasize that what characterizes our relationships in the group is strong feelings of trust and joy. (Personal interview, March 16, 2018)

Overall, it seems that the refugee squats emerge not only as an alternative to the state-run camps but also as an experiment that highlights the importance of the refugees' social and political rights to the city. This is an utterly political decision and experience, and during the last three years, the state has evicted more than 15 refugee squats in Athens and Thessaloniki and relocated the refugees to the camps. Nonetheless, the experiment in self-organized residential common spaces provided fruitful material regarding the political and social field of relations, as well as a basis from which to rethink the refugees' right to housing and the city.

\section{Concluding Remarks: Refugee Common Spaces vs. State-Run Camps}

Given the findings of our research, it becomes clear that the question of refugees' right to housing and the city constitutes a constant field of conflict between state planning policies and the social practices of commoning, solidarity, and self-organization. To conclude, we would like to emphasize three main arguments for the refugees' spatial justice.

First, state policies seem to follow the logic of spatial enclosures, leading to marginalization and exclusion of refugees to isolated and invisible ghetto-like spaces. According to our research, planning policies of the state concerning the location choice of state-run camps in Athens and Thessaloniki followed a top-down procedure which failed to take into consideration and consult local authorities. This harms the well-being of refugees and limits their acceptance by the local communities. This is more obvious in Thessaloniki, where the quantitative ratio of refugees to the local population is higher than Athens and most of the state-run camps are concentrated in the western part of the city, while in Athens there is a more equal allocation around the urban area. Yet, in both cities, state-run camps are overcrowded, are far from the city centres, with a lack of access to public services, health and education facilities, and employment opportunities, as well as being located in extremely degraded, polluted, and dangerous environments. In general, the state policies of refugee camps failed to comply with international design standards for refugee accommodation centres as well as to national urban planning legislation, and refugees are forced to navigate through multiple physical and social borders, obsta- cles and controls in order to access the city centre and its urban social life.

Second, the emergence of housing common spaces for refugees in central areas of Athens and Thessaloniki describes how the possibility for transnational practices of cohabitation, sharing of common-pool resources, and direct democratic organization is actualized. It shows that refugees often contest the institutional regimes of marginality manifested in the segregated areas of the state-run camps and invent and establish housing common spaces in collaboration with local and international solidarity groups, claiming residence in the centre of the city. This actualization is not free of limitations since sometimes the common housing projects do not follow the set living standards, as large numbers of people move in and rooms in the occupied buildings become overcrowded. Still, it seems that refugees prefer to live in squats rather than state-run camps. But as stressed above, this entails constant and hard negotiations to manage power relations across gender, nationality, and religion in decision-making processes. These challenges must be taken into consideration when analysing refugee housing experiments to move beyond the tendency to idealize them. However, it seems that the main reason that motivates people to create and sustain the refugee squats is their central location in the urban fabric that enables easy access to social services and employment opportunities, as well as the sense of solidarity with and belonging in the community. What is especially important here, are the social relations of urban commoning. According to Linebaugh (2008, p. 275), the basic principles of commoning are "anti-enclosure, neighbourhood, travel, subsistence, and reparation." Indeed, our research shows that these features of commoning are present in the refugees' housing squats examined here, as they are spaces which stand in opposition to the enclosures of state-run camps, and which provide safe space for refugee travellers' subsistence and reparation, while at the same time being located in central urban neighbourhoods.

Third, these cases provide ample evidence of, and a framework that documents, the autonomy of this migration approach. This approach is further enriched with details of the spatialities of refugees' right to the city and especially, to the centre of the city. This was based on our research focus and analysis of the active role and creativity of newcomers, the way they built mutual support and constructed solidarity residential common spaces in the urban centres of Athens and Thessaloniki. The inventing practices of collective housing and the agentive processes of being-in-common, challenge and contest the disempowering mainstream discourse of "victimhood" (Mezzadra, 2010, p. 128) and the institutional marginalization and stigmatization of refugees. Furthermore, the central location of the occupied residential common spaces and the political significance they give to gender issues enable renewed claims of women, queer, and transgender refugees' right to the city (Fenster, 2005). 
Moreover, the housing common spaces portray the potentiality of refugees to produce new spatialities and access the "shared experience" (Stavrides, 2019, p. 8) of urban life. We strongly argue that such housing projects created by refugees can open up the centre of the city and the experience of urban life to newcomers and vice versa.

\section{Acknowledgments}

The scientific publication was carried out under the call for proposals "Invitation for the Participation of Doctoral Degree Holders in Post-Doctoral Studies Scholarship" of the University of Thessaly, which is being implemented by the University of Thessaly and was funded by the Stavros Niarchos Foundation.

\section{Conflict of Interests}

The authors declare no conflict of interests.

\section{References}

Afouxenidis, A., Petrou, M., Giannaki, D., Kandylis, G., \& Tramountanis, A. (2017). Dealing with a humanitarian crisis: Refugees on the Eastern EU border of the island of Lesvos. Journal of Applied Security Research, 12, 7-39.

Agustín, O. G., \& Jørgensen, M. B. (2019). Solidarity and the 'refugee crisis' in Europe. London: Palgrave Macmillan.

An Architektur. (2010). On the commons: A public interview with Massimo De Angelis and Stavros Stavrides. e-flux. Retrieved from https://www. e-flux.com/journal/17/67351/on-the-commonsapublic-interview-with-massimo-de-angelisandstavros-Stavrides

Asylum Information Database. (2018). Applications and granting of protection status at first instance. Asylum Information Database. Retrieved from https://www.asylumineurope.org/reports/country/ greece/statistics

Bakewell, O. (2010). Some reflections on structure and agency in migration theory. Journal of Ethnic and Migration Studies, 36(10), 1689-1708.

Bollier, D., \& Helfrich, S. (Eds.). (2015). Patterns of communing: The commons strategies group in cooperation with off the commons books. Amherst, MA: Levellers Press.

Caffentzis, G. (2010). The future of "the commons": Neoliberalism's "plan b" or the original disaccumulation of capital? New Formations, 69(1), 23-41.

Chatterton, P. (2010a). Seeking the urban common: Furthering the debate on spatial justice. City, 14(6), 625-628.

Chatterton, P. (2010b). In autonomy: The struggle for survival, self-management and the common. Antipode, 42(4), 897-908.
Coordination Centre for the Management of Refugee Crisis in Greece. (2016). Summary statement of refugee flows at 12.07.2016. Coordination Centre for the Management of Refugee Crisis in Greece. Retrieved from http://www.media.gov.gr

De Angelis, M. (2010). The production of commons and the "explosion" of the middle class. Antipode, 42(4), 954-977.

Della Porta, D. (Ed.). (2018). Solidarity mobilizations in the "refugee crisis": Contentious moves. London: Palgrave Macmillan.

EUR-Lex. (1997). Council directive 96/82/EC of 9 December 1996 on the control of major-accident hazards involving dangerous substances (10/13/14-01-1997). Brussels: European Union.

European Council. (2016, March 18). EU-Turkey statement [Press Release]. Retrieved from https:// www.consilium.europa.eu/en/press/press-releases/ 2016/03/18/eu-turkey-statement

European Council on Refugees and Exiles. (2007). ECRE policy briefing on housing for refugees and migrants in Europe. Brussels: European Council on Refugees and Exiles.

Faist, T. (2000). The volume and dynamics of international migration and transnational social spaces. Oxford: Clarendon Press.

Fenster, T. (2005). The right to the gendered city: Different formations of belonging in everyday life. Journal of Gender Studies, 14(3), 217-231.

Gemenetzi, G., \& Papageorgiou, M. (2017). Spatial and social aspects of the housing policies for refugees and immigrants in Greece: A critical overview. The Greek Review of Social Research, 148, 39-74.

Greek Council for Refugees. (2019). Country report Greece. Brussels: Asylum Information Database.

Greek Government. (2004). Approval of urban standards and maximum density limits applicable to the preparation of general urban plans (Government Gazette 285D05.03.2004). Athens: Greek Government.

Greek Government. (2011). General urban plan of Echedoros municipality (Government Gazette 304/ААП/7.11.2011). Athens: Greek Government.

Greek Government. (2018). Law 4540: Adaptation of Greek legislation to the directions of Directive 2013/33/EU of the European Parliament and of the Council of 26 June 2013 on the requirements for the reception of applicants for international protection (Government Gazette 91A/22.05.2018). Athens: Greek Government.

Hardt, M., \& Negri, A. (2009). Commonwealth. Cambridge, MA: Harvard University Press.

Harvey, D. (1996). Justice, nature, and the geography of difference. Oxford: Basil Blackwell.

Harvey, D. (2012). Rebel cities. London and New York, NY: Verso.

International Rescue Committee. (2016). IRC deeply concerned over poor humanitarian standards at refugee transit sites in Greece. International Rescue Com- 
mittee. Retrieved from http://www.rescue.org/blog/ refugee-crisis-latest-updates-storify

Kreichauf, R. (2018). From forced migration to forced arrival: The campization of refugee accommodation in European cities. Comparative Migration Studies, 6(7), 1-22.

Lafazani, O. (2018). Homeplace plaza: Challenging the border between host and hosted. South Atlantic Quarterly, 117(4), 896-904.

Lefebvre, H. (1996). Writings on cities. Oxford: Blackwell. (Original work published 1968)

Liapi, M., Charidou, E., \& Tyrovolas, T. (2016). Study of the needs of women refugees living in temporary accommodation structures. Athens: Center for Research on Women's Issues Diotima.

Liapi, M., Giannopoulou, C., Tyrovolas, T., KountouriTsiami, E., \& Saratsi, S. (2019). Accessibility and barriers to gender-based violence services for refugee and migrant girls, boys, women and men in Greece. Athens: Center for Research on Women's Issues Diotima.

Linebaugh, P. (2008). The Magna carta manifesto: Liberties and commons for all. Berkeley, CA: University of California Press.

Massey, D. S., Arango, J., Hugo, G., Kouaouci, A., Pellegrino, A., \& Taylor, J. E. (1993). Theories of international migration: A review and appraisal. Population and Development Review, 19(3), 431-466.

Mezzadra, S. (2010). The gaze of autonomy: Capitalism, migration, and social struggles. In V. Squire (Ed.), The contested politics of mobility: Borderzones and irregularity (pp. 121-142). New York, NY: Routledge.

Mezzadra, S., \& Neilson, B. (2013). Border as method, or, the multiplication of labour. Durham, NC: Duke University Press.

Ministry of Interior. (2015). Meeting of the Minister of Immigration Policy Mr. Giannis Mouzalas with the Central union of municipalities of Greece (K.E.D.E.). Ministry of Interior. Retrieved from https:// www.ypes.gr/synantisi-toy-anapliroti-ypoyrgoymetanasteytikis-politikis-k-gianni-moyzala-me-tinkentriki-enosi-dimon-ellados-k-e-d-e

Ministry of Interior, General Secretariat for Civil Protection, \& Department of Emergency Planning and Response. (2009). Preparation of master plan for largescale technological accident response "SATAME" and prefectural and regional "SATAME" in the implementation of the Ministry of Local Government Administration 1299/2003 “Xenocrates" (4498/25-06-2009). Athens: Ministry of Interior.

Olmos, D. (2019). Racialized im/migration and autonomy of migration perspectives: New directions and opportunities. Sociology Compass, 13(9). https://doi.org/ 10.1111/soc4.12729

Papadopoulos, D., Stephenson, N., \& Tsianos, V. (2008). Escape routes: Control and subversion in the 21st century. London: Pluto Press.

Papadopoulos, D., \& Tsianos, V. (2013). After citizen- ship: Autonomy of migration, organisational ontology, and mobile commons. Citizenship Studies, 17(2), 178-196.

Pasquetti, S. (2015). Negotiating control: Camps, cities and political life. City, 19(5), 702-713.

Pechlidou, E., Frangopoulos, Y., \& Hatziprokopiou, P. (2020). The spatial management of the "migration crisis" and local opposition: Public discourse, actors and reactions against refugee accommodation in Thessaloniki. In A. S. Markou \& M. Zlatkova (Eds.), Post-urbanities, cultural reconsiderations and tourism in the Balkans (pp. 137-160). Athens: Éditions Hêrodotos.

Ramadan, A. (2013). Spatialising the refugee camp. Transactions of the Institute of British Geographers, 38(1), 65-77.

Refugee Accommodation and Solidarity Space City Plaza. (2019). 39 months City Plaza: The end of an era, the beginning of a new one. Solidarity 2 Refugees. Retrieved from http://solidarity2refugees.gr/39-minescity-plaza-oloklirosi-enos-kyklou-archi-enos-neou

Regulatory Urban Plan of Athens and Thessaloniki Metropolitan Areas. (2014). Draft law new regulatory urban plan of Athens and Thessaloniki metropolitan areas. Ministry of Environment and Energy. Retrieved from http://www.opengov.gr/minenv/?p=5935

Ristau, J. (2011). What is commoning, anyway? On the Commons. Retrieved from https://www. onthecommons.org/work/what-commoninganyway

Rozakou, K. (2012). The biopolitics of hospitality in Greece: Humanitarianism and the management of refugees. American Ethnologist, 39(3), 562-577.

Ruivenkamp, G., \& Hilton, A. (2017). Introduction. In G. Ruivenkamp \& A. Hilton (Eds.), Perspectives on communing: Autonomist principles and practices (pp. 1-24). London: Zed Books.

Soja, E. W. (2010). Seeking spatial justice. Minneapolis, MI: University of Minnesota Press.

Stavrides, S. (2019). Common spaces of urban emancipation. Manchester: Manchester University Press.

Trimikliniotis, N., Parsanoglou, D., \& Tsianos, V. (2015). Mobile commons, migrant digitalities and the right to the city. Basingstoke: Palgrave Macmillan.

Tsavdaroglou, C. (2018). The newcomers' right to the common space: The case of Athens during the migrant crisis. ACME, 17(2), 376-401.

Tsavdaroglou, C. (2019). Reimagining a transnational right to the city: No border actions and commoning practices in Thessaloniki. Social Inclusion, 7(2), 219-229.

Turner, S. (2016). What is a refugee camp? Explorations of the limits and effects of the camp. Journal of Refugee Studies, 29(2), 139-148.

United Nations Committee on Economic, Social and Cultural Rights. (1991). General comment no. 4: The right to adequate housing. Geneva: United Nations Committee on Economic, Social and Cultural Rights. 
United Nations High Commissioner for Refugees. (2007). Handbook for emergencies. Geneva: United Nations High Commissioner for Refugees.

United Nations High Commissioner for Refugees. (2014). The right to adequate housing: Fact sheet N.o 21 (rev. 1). Geneva: United Nations High Commissioner for Refugees.

United Nations High Commissioner for Refugees. (2019). Greece. Geneva: United Nations High Commissioner for Refugees.

Wacquant, L. (2007). Territorial stigmatization in the age of advanced marginality. Thesis Eleven, 91, 66-77.

Ziindrilis, Y., \& Dalakoglou, D. (2019). Camps and ruins: Notes from Greece on the visual representation of the 2015 "refugee crisis." Visual and New Media Review. Retrieved from https://culanth.org/fieldsights/ camps-and-ruins-notes-from-greece-on-the-visualrepresentation-of-the-2015-refugee-crisis

\section{About the Authors}

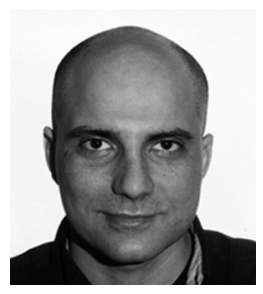

Charalampos Tsavdaroglou is a Postdoctoral Researcher in the Department of Planning and Regional Development at the University of Thessaly, Greece. He holds a PhD in Urban and Regional Planning, School of Architecture, Aristotle University of Thessaloniki, Greece. His research interests include critical urban theory, the autonomy of migration, common space and urban social movements, intersectional, decolonial, and affective geographies, on which he has published several journal articles and book chapters in English and Greek.

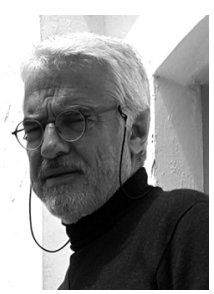

Konstantinos Lalenis (M.Eng., PhD) is a Professor in the Department of Planning and Regional Development, University of Thessaly, Volos, Greece. His specialization is in Urban Planning and Urban Governance. He was awarded for Excellence in Teaching by AESOP, and for Academic Excellence by the Greek Ministry of Education. Current research interests include participation and governance issues, planning law and institutional frameworks, strategic planning, and in the use of blockchain technology in urban planning, within the frame of urban resilience. 